Original Article

\title{
Path to the Universal Self in Haji Baktash Walî: Four Doors - Forty Stations
}

\author{
Erdem Sevim ${ }^{1}$ \\ Hakkari University
}

\begin{abstract}
This work aims to discover the shared psychological characteristics between Haji Bektash Walî’s desire to "be in a state of unity," as described in his teaching of "Four Doors - Forty Stations (Dört Kapı Kırk Makâm)," and the concept of the "universal self" appearing in humanist psychology's emphasis on humans' "transcendental need." In connection with these two concepts, this work will search out the similarities between the Sufi notion of reaching one's God-created human perfection (insân-i kâmil) and humanist psychology's concept of self-actualization. In Turkey, Haji Baktash Walî is not only the symbol of folk Sufism, itself founded on peace, love, and acceptance, but also a true man of hearts. This article not only examines the states (ahwâl) experienced while on a spiritual journey toward reaching the universal self are evaluated in light of these two approaches, but also the similarities between peak experiences and mystical experiences and the change and transformation they lead to in one's character.
\end{abstract}

Keywords

Haji Baktash Walî • Sufism • Humanist psychology • Peak experiences

\section{Hacı Bektaş-i Veli’de Evrensel Benliğe Giden Yol: Dört Kapı Kırk Makam}

Öz

Bu çalışmada barış, sevgi ve hoşgörüyü temel almış halk sufiliğinin simgesi ve bir gönül adamı olan Hacı Bektaş-1 Veli'nin inanç felsefesi ve bu inancın somutlaştırıldığı "Dört Kapı Kırk Makam" oğretisi ele alınmış; Hacı Bektaş-i Veli' de "birlik olma" arzusunda, Hümanistik psikoloji de ise "aşkınlık ihtiyacı"nda karşımıza çıan "evrensel benlik" vurgusu, İnsan-ı kâmil ve kendini gerçekleştiren kişilerinin ortak psikolojik niteliklerinden yola çıkarak ele alınmaya çalışılmıştır. Evrensel benliğe doğru alınan bu manevi yolculukta yaşanan haller ise bu iki yaklaşım doğrultusunda değerlendirilmiş olup; doruk deneyimler ve mistik deneyimler hem benzerlikleri hem de insan kişiliğinde yarattığı değişim ve dönüşüm gücü açısından incelenmiștir.

Anahtar Kelimeler

Hacı Bektaş-i Veli • Sufilik • Hümanist psikoloji • Doruk deneyimler

1 Correspondence to: Erdem Sevim, Educational Sciences Department, Hakkari University, Hakkari 30000 Turkey. Email: erdemsvm@hotmail.com

Citation: Sevim, E. (2016). Path to the universal self in Haji Baktash Walî: Four doors - forty stations. Spiritual Psychology and Counseling, 1, 145-161. http://dx.doi.org/10.12738/spc.2016.2.0014 
"What makes a human is not his foot and his head, To be Human is to be a meaning, not simply a face and an eyelash..."

Kaygusuz Abdal

\section{Life and Works}

Although there has been an increase in studies on Haji Baktash Walî and his teaching of "Baktashiism" both in Turkey and internationally in recent years, a many of these studies have yet to properly characterize and interpret this historical phenomenon. Yet, the existence of serious studies conducted in this area has shown that a correct understanding of Haji Baktash Walî is connected to being able to conceive of his historical and mythological (menkabevî) personality (Ocak, 2008). Ocak, in examining Haji Baktash Walî and his teaching of Baktashiism, has found that this field touches not only on historical problems, but on fundamental problems related to science and current events as well. While Ocak considers historical problems to be "historical distortion" of different ideological and theological traditions, he emphasizes that current problems are a result of a sensitivity toward political and theological issues. No matter how many difficulties these two problems cause in a reading of history, there is essentially another problem identified by Ocak demanding extra attention due to the scope of this article, this problem being the "scientific problem." By scientific problem, what is meant is the problem pertaining to the lack of historical sources, documents, and information on Haji Baktash-i Walî (Melikoff, 2010a; Ocak, 2008).

It is only possible to examine Haji Baktash Walî using secondary sources. A list of known works in chronological order begins with Manâqibu'l-Qudsiyyah: a type of mythological family history written by the grandson of Wafâ‘î Sheikh Baba Ilyas, Elvân Chelebi (D: 1359AD), who was also the son of the famous $14^{\text {th }}$ century Sufi Âshiq Pasha. Although Haji Baktash Walî is only mentioned by name in this work, it constitutes an authoritative account of the type of family in which Haji Baktash was raised and his place in it. The next work is Manâqibu'l- 'Arifin, written in Farsi by the Mevlevî Dervish, Ahmed Eflaki, in the $14^{\text {th }}$ century (1318-1353) as a result of Jalâluddîn Rûmî's request for such a work's composition. In this work, although only very little space is allotted to Haji Baktash-i Walî, its importance is in its being a standard delineating Sufi qualities and a point of reference to ensure the validity of the other sources used (Ocak, 2008). Next in chronological order is Maqâlât. Being composed primarily of Haji Baktash Walî's teaching of the "Four Doors Forty Stations (Dört Kap1 Kırk Makam)" and other Sufi treaties, this $15^{\text {th }}$ century work delineates the general dictates of Baktashiism (Coşan, 2013). Next is the of Book of Haji Baktash's Sainthood (Velâyetnâme-i Hacı Bektaş), written during both the $15^{\text {th }}$ and first quarter of the $16^{\text {th }}$ centuries. This work takes Haji Baktash Walî as 
its primary subject of discussion and therefore constitutes an important resource in explaining Haji Baktash in the historical and belief paradigm dominant during his life (Çakmak, 2015). The mutual feature found in all of the above works is the emphasis placed on Haji Baktash Walî’s heterodox identity (Ocak, 2008). Finally, Köprülü and his student Abdülbaki Gölpınarlı are both worth important mention not only for their work in bringing the above works to the attention of Turkey, but also for their own research on the problem of Muslims and Islam in Anatolia and their contributions to the pool of knowledge on such issues (Eröz 1990; Melikoff, 2010a; Ocak, 2008).

As an individual in history, there is a consensus that Haji Baktash Walî was born in the city of Nishabur, Khorasan and is estimated to have lived between 1209 and 1271 $\mathrm{AD}$, eventually migrating to Anatolia and settling in the town of Sulucakarahöyük as a result of the Mongol invasions of Central Asia (Göçgün, 1998; Melikoff, 2010a; Ocak, 2008). There is a difference of opinion as to which Sufi group Haji Baktash Walî belonged. Basing his conclusions on information gleaned from Velâyetnâme, Gölpınarl1 (1995) states that Haji Baktash Walî came to Anatolia after having pledged allegiance to Sheikh Ahmad Yasawî through the medium of Loqmân Parande. Melikoff (2010a), however, is of the opinion that Haji Baktash Walî was a highranking follower (murîd) of Wafâ‘'̂ Sheikh Baba Ilyas, basing her conclusion on the works of Elfaki, 'Âshiq Pashazâde, and Elvân Chelebi. Ocak (2008), on the other hand, holds that Haji Baktash Walî came to Anatolia as a Haydarî dervish and that only after having arrived in Anatolia did he accept Baba Ilyas as his Sheikh and pledge his allegiance to him. With this being said however, during Haji Baktash Walî's time in Anatolia, it is generally accepted that he was not a member of any fullyfunctioning religious order (tarîqah) and was more of an opinion leader. Moreover, there is no mention of the existence of any religious-social group that could be labeled "Baktashî" during his time in Anatolia (Y1ldırım, 2015). Baktashiism attained its identity as a separate institution as a result of its second grand master, Balim Sultan (Küçüközyiğit, 2014; Melikoff, 2010b). Today however, Haji Baktash Walî is not only a holy individual accepted in Anatolia, he is also seen as such in Albania, Bosnia Herzegovina, Macedonia, Greece, Hungary, and Azerbaijan (Melikoff, 2010b).

\section{The Concepts of Humanity and Universalism According to Haji Baktash Walî}

Being a symbol Sufism whose name has been given to a Sufi order, Haji Baktash Walî's school of thought, like those of other Sufi schools, is founded on an approach focusing on humanity (Durakoğlu, 2015; Melikoff, 2010b). The dominant idea held by Haji Baktash Walî was the belief that all of creation is unified within the existence of God and is but a manifestation of Him (wahdatu'l-wujûd). This belief also attested to the unity of human-universe-God, holding that both the universe and humans were of the very same essence. According to this understanding, every 
human being carries in him an existential spark able unite him with his source of existence. The very foundation of this philosophy lies in the understanding of the "singleness, uniqueness, and oneness of God and of that of creation (tawhîd)." Just as the sentence "Whatever exists in the universe, its example is found in Adam (man)" is based on this understanding, so too is the idea that nature and the universe are a clear manifestation of God, who shows His perfection (quddûsiyyah) in humans who have reached God-created human perfection (insân-i kâmil) (Güray, 2010).

The goal of this human-centered understanding is to provide a way for humans to become aware of their own essence by aiding them in perfecting themselves. According to Haji Baktash Wali, the nature of humanity is composed of both good and evil at the same time and if one were to be left to his own devices, evil would take full control over him. Every human has opposite penchants toward good and evil, beauty and ugliness, truth and falsehood, generosity and stinginess, acceptance and disdain. Only by inclining to that which is good, which entails going through a process of internal purification of his evil penchants, can one become closer to God and reach spiritual perfection (Aytaş, 2010). According to Haji Baktash Walî, individual humans possess free will and are therefore responsible for their actions. That which distinguishes humans from other creatures of God is that humans have the ability to use their gift of reason to discriminate between right and wrong, good and evil and make a conscious decision when faced with a variety of options from which he must choose. Here, although humans are free to choose, the sentence "Free, but not independent" is telling in that it emphasizes humans' need for a manual or spiritual mentor on his path toward perfection and in inclining himself to that which is good (Sever, 2009). It is essential for one on this path (sâlik/murîd) to attach himself to a spiritual mentor (murshid) whose role is to use his own personal experiences and accumulated knowledge not only to open and enlighten this path, but also to present different options to the one travelling upon it (Gübiz, 1966).

Similar to other Sufi schools of thought, Haji Baktash Walî’s universalism is founded on the teaching of unity of existence and human creation, in which both nature and man carry the same divine essence. Not only is accepting the idea that all humans are citizens of the world is facilitated by espousing a holistic HumanUniverse-God worldview, it is also the means for one to attain a profound level of acceptance of others' differences. This approach is manifested in the following words: "Seeing seventy-two nations as but one / Having no disdain for seventy-two nations / Seventy-two nations are but a single nation to us / All that is created in this world is naught but equal" (Öz, 1997). It is possible to see the three fundamental values of universalist perspective, a general love for nature and humans, and peace and fraternity on which this belief is based in the following poem: 


\section{"Love and affection burn in our burning hearth}

Hummingbirds spring to life; roses bloom in are gardens

Ambition and hate destroyed, love is abound

Lions and gazelles are friends in our warm embrace"

\section{Spiritual Education According to Haji Baktash Walî}

Heat is in the fire, not on the kiln.

Marvels manifest in the head, not the crown

Whatever it be that you are seeking, seek it in yourself

It's not in Jerusalem, Mecca, nor while on the pilgrimage to Hajj

Haji Baktash Walî classifies people into two categories in his educational paradigm; these being a "mature individual" and a "raw individual." A mature individual is one who has received education and has attained the ability to be a guide to others, describing such people as murshid or pîr. Raw individuals are defined as those who are ready to receive education (Öz, 1997). Four fundamental dimensions pertaining to a raw individual's potential education may be mentioned: (1) Internal education pertains to moral principles and rules are to be internalized and practiced in one's daily life, (2) Horizontal education pertains to social support and control, (3) Vertical education pertains to one's attachment to a spiritual leader, such as a murshid or pîr, and (4) identity pertains to the knowledge that one has attained and then protecting the secret that one has been bestowed while aiming to share it only with others able to properly carry it (Aktürk \& Tuğrul, 2014). In general however, the fundamental goal of this education is to produce individuals who have reached the potential created for them by God (insân-1 kâmil) beginning with disciplining one's flesh (tarbiyatu'lnafs). No matter how much education places an individual in the center, it is by no means an individual venture. One who has attained his God-created human perfection (kamâlât) enters into society carrying this secret with the goal to serve society and its members. As a result of this spiritual education, a person "sets out to migrate (hijrah), which in essence means to overcome one's flesh (nafs), directing himself to his heart (kalb), then to his secret (sir), then to his spirit (rûh), then to 'The Eternal Truth' (elHaqq), and finally from Truth to creation" (Korkmaz, 1999). To put it another way, one of the fundamental goals is to reach transcendental knowledge (sir) and then to raise society and humanity using this knowledge (Kurşunoğlu, 2014).

When looking at the relation between the heart (kalb), flesh (nafs), and reason ('aql), Haji Baktash Walî likens the heart to a city, stating that this city has two supreme authorities, The All-Merciful (Rahmân) and Satan (Çetinkaya, 2009). The name of the All-Merciful Sultan is reason, its deputy is belief (îmân), and its 
lieutenant is poverty. The All-Merciful Sultan has seven towers, each of which represents a guardian (wakîl). These guardians are knowledge, generosity, humility (hayâ), patience, abstinence, fear, and morality (adab). What is meant by the Satanic Sultan is the Devil (Iblis), its deputy is the flesh (nafs), and the guards of its seven towers are arrogance, gluttony, stinginess, envy, anger, backbiting, excessively loud laughter, and buffoonery. Whichever of these two sultans rules over a person's heart depends on one's struggle between his flesh and reason, and it is this struggle which Haji Baktash Walî calls the battle between light and darkness. In Maqâlât, man is created from types of darkness and is enlightened from three different objects. The first type of darkness from which man is created is the four fundamental elements (earth, fire, water, and air) and is enlightened by the light of reason ('aql). The second darkness from which man is created is ignorance, which is to be enlightened by the light of knowledge ('ilm). The third darkness is one's flesh (nafs), which receives enlightenment from the light of divine knowledge, known as ma 'rifah (Coşan, 2013).

An 'ârif is the Arabic name for one who possesses the light of divine knowledge (ma'rifah) and as such it is the ârif who not only transforms his base knowledge ('ilm) into deep divine knowledge ("irfân)", but who are aware that belief (îmân) is above reason ('aql). Beginning his journey by adopting proper morals (adab), irfân is what one gains after having successfully completed this edifying journey. One of the various goals on this education is to provide a means for base knowledge to be transformed into 'irfan by using one's capacity of reason, which can only be achieved by being purified of one's own internal idols. One who succeeds in doing this must refrain from either breaking or inflicting even the slightest amount of distress on another's heart (Eğri, 2001).

In terms of cultivating people's inner humanity, Sufi schools functioned throughout history as unofficial institutions of education. One who has set out on this path embarks on a journey of spiritual maturation to reach his own God-created human perfection (insân-i kâmil), traversing different stages of his of carnal desires (nafs), overcoming each in a step-by-step process in which he eventually overcomes his ego (Karacoşkun, 2007). In his Maqâlât, Haji Baktash Walî discusses this process of spiritual maturation and the methods effective in transforming a "raw individual," whose spiritual faults and imperfections, into a "mature individual." In this work, Haji Baktash Walî describes the teaching Four Doors - Forty Stations as the method to reach the universal self (Kehl-Bodrogi, 2012).

2 The three words ma 'rifah, 'ârif, and 'irfân are all Arabic words from the same root ( $(\varepsilon-j-\dot{0}$ ) meaning knowledge.This root expresses a different nuance than the other Arabic root $\left(\varepsilon-J_{-}-p\right)$ that also means knowledge and which has been rendered as 'ilm in this article. Both words for knowledge, ma 'rifah and 'ilm, are used in this specific sentence. These roots are used excessively in Sufism, and as such will henceforth be used in their original Arabic forms. 


\section{Four Doors - Forty Stations}

In his work Maqâlât, Haji Baktash Walî describes the steps one is to take upon setting out on his spiritual journey and how the steps will manifest using the concept of four doors and forty stations. This work is a Sufi treatise describing and discussing four door; these doors being (1) Sharî‘ah - the rules of religion, (2) Tarîqah - the Sufi path, (3) Ma'rifah/divine knowledge - 'irfân, and (4) Haqîqah/Truth - the manifestation of divine truth (Melikoff, 2010a; Shankland, 2010). In Maqâlât, a person my only reach God-created human perfection (insân-i kâmil), or in other words becoming one with the transcendental, by traversing through four doors and forty stations. As Haji Baktash Walî openly states, "A worshipper reaches Allah ta'âlâ by passing through forty stations, thereby becoming a (true) friend of His," decreeing ten of the stations to fall under sharî' 'ah, ten under tarîqah, ten under ma 'rifah, and ten under haqîqah. Likening the four doors to the four primary elements, with wind being shari 'ah, fire being tarîqah, water being ma 'rifah, and earth being haqîqah, Haji Baktash Walî also states that there are four primary Muslim characters corresponding to the four basic elements. These four characters are 'âbid/one who performs all his actions as a form of worshipping his creator and lord, zâhid/one who foregoes all worldly comforts for the sake of his creator and lord, 'ârif/one of deep knowledge of one's creator and lord, and muhibb/a lover and absolute devotee of one's creator and lord, corresponding to sharî'ah, tarîqah, ma 'rifah, and haqîqah, respectively (Coşan, 2013).

1- The Door of Sharî'ah/Divine Law: Those at the door of $\operatorname{sharî}$ 'ah are described as 'âbid/worshippers. Worshippers are those who follow the dictates of sharî' ah and whose inner substance is of the wind, which has both purifying and strengthening properties. Worshippers hail from the normal class of society, as opposed to the educated or elite classes of society, who have such negative characteristics as arrogance, envy, hate, stinginess, enmity, and seeking revenge,. Stations within this door are: (1) to believe, (2) to learn knowledge ('ilm), (3) to worship, (4) to earn only what sustenance is permitted (halâl) by its creator in a way that is also permissible, (5) abstaining from that which one's creator has forbidden (harâm), (6) to perform marriages, (7) to marry oneself, (8) to abstain from sexual relation during inappropriate times, (8) to be a member of the community following the tradition of the Prophet Muhammad (saws), (9) to be compassionate, to dress simply and to consume simple foods, and (10) to enjoin that which is right and for abstain from that which is wrong.

2- The Door of Tarîqah/Sufi Path: Those at the door of tarîqah are described as zâhid/forgoers of worldly comforts. Having a nature of fire, a zâhid is described as abandoning the world by performing acts of worship day and night, thereby gaining knowledge of God as well as base knowledge ('ilm) and 'irfân. A zâhid is one who has gained the capacity to struggle against his own flesh (nafs), reaching this stage as 
a result of their own efforts. Stations within this door are: (1) taking the hand of a Sufi sheikh and repenting, (2) willfully becoming a disciple (murîd) of a Sufi sheikh, (3) keeping one's clothes, hair, and beard both clean and in order, (4) struggling against the desires of one's flesh (nafs), (5) serving others, (6) being in a state between excessive fear and hope, (7) taking lessons from and providing guidance to others,(8) distributing God's bounties to others, (9) reaching a state of intense love and a high level of enthusiasm, and (10) seeing his inner essence as poor.

3- The Door of Ma'rifah/Divine Knowledge: The two doors of ma'rifah and haqîqah are considered to be doors of "meaning" during which the traveler on this path attains mystical knowledge and possessor of irfân. One at this stage is described as an 'ârif/one who has deep knowledge of his creator and lord. An 'ârif is described as one who takes on the cleansing and purifying properties of water. For this reason, an 'ârif is considered to be one whose inside no longer contains any evil. While going through this process of internal purification, one at this stage also becomes the means for others on this path to undergo an internal purification. The worship of an 'ârif manifests itself in the form of reflection (tafakkur), abandoning both this world and the next, and waiting to receive (walâyah) while directing all of his enthusiasm and consciousness toward God (himmah). Stations within this door are: (1)proper morals (adab), (2) fear, (3) abstinence, (4) patience and frugality, (5) feeling embarrassment, (6) generosity, (7) knowledge ('ilm), (8) intense poverty, (9) ma'rifah, and (10) knowing oneself.

4- The Door of Haqîqah/Truth: One at the door of haqîqah are "the people of love and devotion (ahl-i muhibb)." A muhibb, having the nature of earth, is not only one who possesses both wisdom (hikmah) and irfân, but also one who is able to attain knowledge using the capacities of his heart, or in other words, through inspiration (ilhâm). One who has reached this stages is considered one who has achieved his God-created human perfection (insân-i kâmil) and who has escaped the clutches of his ego, attaining the highest level of the universal self. Put another way, one attainseternity (baqâ) by knowing himself to be nothing in comparison to his absolute creator, at this stage. Compared to other stages, one who has reached the door of haqîqah has achieved deep internal satisfaction as well as acceptance of and love for others, regardless of who they are, striving to serve humanity with pure sincerity. A muhibb becomes one with the moment, overcoming not only his past quarks, but also his future desires and scruples. By becoming one with the moment, a muhibb escapes duality. Stations within this door are: (1) becoming earth, (2) not scorning the seventy-two nations of humanity, (3) being as merciful and compassionate as possible, (4) not seeing anyone's faults, (5) to be in agreement with the principles of singleness, uniqueness, and oneness of God (tawhid), (6) speaking of the secrets of truth with others, (7) following a specific spiritual path (sayr-i sulukk), (8) secret 
(sirr), (9) beseeching God (munâjât), and (10) witnessing God's manifestation in creation (mushâhadah) (Coşan, 2013).

Four doors and forty stations is a method in which an individual's imperfect deficient spirit (rûh) is transformed into a perfect human spirit (Kurşunoğlu, 2014). This transformation is realized under the guidance of a mentor and by learning who one really is. Learning who one really is means results from one's own personal experiences in mysticism. Mysticism itself means to reach 'irfân through real experiences and due to its being a part of a multitude of belief systems and cultures, has attained a universal aspect. This universal aspect is a reflection of humans' transcendental needs (Karacoşkun, 2007). These transcendental needs can be described as the existential spark and desire in every single individual impelling him to reunite with the (single) source from which they came (Birge, 1991). Maslow, one of the pioneers of humanist psychology, emphasizes both the universality of this transcendental need and the fact that it constitutes an inseparable part of every human being (Elkins, 2007). Haji Baktash Walî's teaching of four doors and forty stations is not only a path to reach true information pertaining to humans' transcendental need, but also a means to attain eternity (baqâ) through becoming united with all of creation, in other words by reaching the universal self. In order to do this, an individual traverses different stages abiding by the above-described methods and techniques, attaining knowledge of the truth as a result of his own personal experiences and transcendental sources. Having reached mental and spiritual maturity, one who has attained knowledge of truth [pertaining to the spirit (rûh) and matter] through this tradition is then obliged to pass this information down so as to keep the knowledge contained in the tradition alive and, at the same time, secret (Kurşunoğlu, 2014).

One who proceeds down this şreal-life spiritual journey (sayr-i sulûk) within the teaching of Four Doors and Forty Stations passes through different stations and feels the need to exhibit a different behavior at each station (Odyakmaz, 1988). As a result of one's personal experiences or mystical states (ahwâl), an individual undergoes an emotional transformation. Since this emotional transformation has an effect on one's complete self, it can be described not only as the opening of a path to mental and behavioral changes, but as an opportunity for one to completely reform his personality (Karaçoşkun, 2007; Özelsel, 2002). At its very essence, this spiritual journey is a means for one to understand his own humanity and to be recreated. This process is describedas two different psychological modes in Sufi thought; these being that of transience (fanâ) and of eternity (baqâ). While transience is defined as an individual's leaving behind his flesh (nafs), eternity is defined as uniting with the universal self, thereby attaining one's God-created perfection (Arasteh \& Sheikh, 2003). While traversing each specific stage within the teaching of Four Doors and Forty Stations, one attains a holistic personalityas a result of the mystical states 
(ahwâl) that he experiences and other techniques [e.g. abstinence, repetitive rituals, prayer (duâ)]. In such a case, the two concepts of transience (fanâ) and eternity (baqâ) describe the self-maturation process that one undergoes during his efforts to melt his egoism (anâniyyah), so to speak,so that he might move progressively closer to reaching the universal self (Karaçoşkun, 2007). The steps in this self-maturation process are summarized as follows:

- The Door of Sharî'ah/Divine Law - in which one's flesh (nafs) says "To you is yours and to me is mine."

- The Door of Tarîqah/Sufi Path - "To you is yours, mine is also yours."

- The Door of Ma 'rifah/Divine Knowledge - "There is neither mine nor yours."

- The Door of Haqîqah/Truth - "There is neither you nor I, everything is but He."

\section{Peak Experiences and Mystical Experiences}

From a spiritual perspective, there exist similarities between 'melting one's egoism (anâniyyah)' and moving toward reaching the universal self/unity meaning and self-actualization in humanist psychology. Humanist psychology emphasizes the universality of humans' transcendental needs, holding that every human has, from birth, his own specific way to reach self-actualization (Elkins, 2007). The similarities between God-created human perfection (insân-i kâmil) discussed in Four Doors and Forty Stations and the characteristics of self-actualization in humanist psychology should be evaluated to reflect a holistic perspective. The psychological characteristics of a human having attained his own God-created perfection (insân-i kâmil) are as follows (Sayar, 2003):

- Being saved from duality,

- Being saved from fear, ambition, and sexual/aggressive impulses,

- Becoming experienced in different stages on a spiritual journey,

- Living in complete harmony and becoming one with the moment,

- Overcoming the individualist ego appropriated to him by society,

- Being unified and as one with everything in creation,

- Experiencing such intense emotions as hope, fear, cheerfulness, confidence, and security in one's everyday life,

- Having a transcendental experience,

- Discovering one's link between with the hidden rhythm of nature and all the universe, and 
- Attaining a feeling of being existentially complete.

The characteristics of one reaching self-actualization in humanist psychology are:

- Overcoming subjectivity in one's perception of reality,

- Accepting oneself as one is,

- Having a highly-developed sense of responsibility,

- Behaving in a simple and honest manner,

- Having a need for independence, autonomy, and privacy,

- Having intense mystical and supernatural experiences,

- Being empathetic, accepting of others, and full of love,

- Able to resist a conformist life style,

- Espousing democratic attitudes

- Being creative,

- Working to improve society and humanity (Schultz \& Schultz, 2007).

Among the more out standing similarities between attaining one's God-created human perfection (insân-i kâmil) in the teaching of Four Doors and Forty Stations and the concept of self-actualization in humanist psychology are the humanist values of acceptance of others, love, and empathy as well as a shared emphasis on achieving harmony with oneself. Likewise, while according to Haji Baktash Wali, the fact that an individual carries an existential spark to become unified with the transcendent one, according to Maslow holds that humans possess a higher, more transcendental nature than they aware of, emphasizing this to be an existential piece of all humans (Durakoğlu, 2015; Maslow, 1996). Maslow (1996) furthermore describes the states (ahwâl) and mystical experiences that one undergoes while on his spiritual journeyas manifested in Four Doors and Forty Stations - as "peak experiences." People in peak experiences are able "to transform means activities into end-activities, to "ontologize;" to see voluntarily under the aspect of eternity, to see the sacred and symbolic in and through the individual here-and-now instance." According to Maslow, that fact that we do not have the ability to experience "peak experiences," we are unable to discover our essence at a conscious level means that we have not become full humans and are ever unable to overcome subjectivity. In stating that pain, sickness, fear, personal self, and character traits hindering one from having a peak experience, Maslow, in essence, concurs that internal personal purification may be achieved through performing the duties and following the guidance (nasîhah) detailed in the teaching of Four Doors and Forty Stations (Korkmaz, 1999; Maslow, 1996). 
Maslow (1996) emphasizes that these just as these experiences have both a naturalist appearance and a theological aspect, able to be considered mystical experiences inside their own historical context. For example:

1. The perception that the entire universe is a complete whole in a state indivisible union constitutes the point of consensus in peak experiences and is found in the ability to reach unity and the universal self within the Door of Haqîqah/ Truth. It is further emphasized that the states (ahwâl) undergone during these experiences cannot be expressed in words, but are a personal and internal essence. Perceiving oneself to be in the universe as one of its parts while also belonging to the moment in which one finds himself may not only generate both deep and shocking effects in a person, but may also lead to significant changes in his personality.

2. An individual caught in the flow of worldly events perceives the world according to his own interests, subject to somewhat selfish penchants. In other words, our self not only defines our limits, it also hinders us from being able to perceive the transcendental one. The knowledge gained of oneself and one's ability to perceive his own essence during peak experiences provides one the opportunity to perceive objects independent of his worldly sensors. The perception one attains during peak experiences is one in which the personal is completely removed, one that is devoid of egotism and selfishness.

3. As a result of transcending physical boundaries, a person experiences dissonance between time and space during peak experiences. In other words, one has an experience with the universal and the infinite.

4. Peak experiences are another way to becoming "Godly." In this way, not only does one gain awareness that good and beauty are without limit whereas evil is limited, he also comes to the realization that it is the product of an ego-centric understanding. One therefore realizes that a universal understanding is not only good-oriented, but also inclines toward virtuous feelings and behaviors. The possible feelings and reactions that one at this level has are helpfulness, politeness, cheerfulness, love, acceptance of others, and possibly sadness. Haji Baktash Walî states that "Responding to evil with good is the profit of a mature individual."

5. Contrary to ordinary cognition, being-cognition during peak experiences is a more passive, open to receiving, and humble method of perceiving. Ordinary cognition is an active process in which more energy is spent and in which the individual not only constructs and chooses how and what to perceive, but also must remain awake and at the wheel, so to speak. Being-cognition, also known as existence-cognition, on the other hand, is more passive and open to receiving in which a person is in the most conducive position to listen, hear, 
and understand. The fundamental characteristic of this method of perceiving lies in one having overcome his ego, in which he no longer thinks of himself., and selfless.

6. Peak experiences are the means to overcome or to solve instances of division and separation experienced in life. Peak experiences are a result of one perceiving this world to be united and a whole. By reaching the universal self, a person essentially melts his ego so as to become one with all of creation and thereby avoids polarization and experiencing instances of separation.

7. Peak experiences are the means to one experiencing dramatic changes in his life style. Sometimes these experiences are so powerful that an individual can continue his life as a completely different person.

8. During peak experiences, a person feels more responsible, active, creative, and free compared to other times.

9. One who has had and who has accepted to have had a peak experience is one who has a more open and more powerful identity, who is able to overcome his self, and who devoid of self.

10. One who has had a peak experience is a more spiritual and transcendental person who is more concerned with psychological laws as opposed to physical laws and who lives at a level described as "high life" (Maslow, 1996).

According to Maslow (1996), peak experiences make people, "move more closely to a perfect identity, or uniqueness, or to the idiosyncrasy of the person or to his real self, to have become more a real person." Maslow states that since the characteristics that manifest during peak experiences are unalterable truths, they form universal, essential human values. These characteristics are honesty, integrity, beauty, completeness, liveliness, originality, perfection, justice, richness, effortlessness, cheerfulness, and self-sufficiency. Haji Baktash Walî likens the mystical experiences that one has to sparks of light that enlighten one's heart for a limited period of time and then which extinguish. These experiences can occur at any point during one's spiritual journey, whether to one who has newly entered the path or to one who has attained his God-created human perfection (insân-i kâmil). This spark has the ability to enlighten a veiled part of one's spirit (rûh) and encourage him to reach the stage on his spiritual journey. These mystical experiences (ahwâl) are had in conjunction with a series of behavioral stations (maqâm). Carrying moral (akhlâqî) properties and are loaded with a myriad of values, these behaviors form a complementary relation with the states (ahwâl) one experiences. Here, it is emphasized that in addition to the states (ahwâl) one experiences, these stations are of a hierarchal nature that exert a permanent effect on the person experiencing them. Once a person internalizes the behaviors defining a specific station (maqâm) his character undergoes a complete transformation (Coşan, 2013; Özelsel, 2002; Sayar, 2003). 
One of the similarities between Haji Baktash Walî's understanding and humanist psychology is their embracing a holistic perspective that provides a basis for humanist psychology to allow religious beliefs and spirituality to have an effective role in individual and communal activities as well as in the cultural manifestation within individual thought (Powers, 2003). Since at the core of humanist psychology lies the concept of self-actualization and spiritual well-being, spiritual well-being can be considered to stem from the same primary components as psychological well-being (Benjamin \& Looby, 1998). Carl Rogers, one of the pioneers of humanist psychology, defines psychological well-being as the highest level of self-actualization. Rogers holds one's self-actualization penchant to be an individual's attempt to become a full individual (Kuzgun, 1972). Not only does Rogers state self-actualization to be the ultimate goal of psychotherapy, he also holds unconditional acceptance of and respect for the patient's world to be what renders this goal's realization possible. According to Rogers, it is this unconditional acceptance and respect that allows a patient to embark on a spiritual journey leading to maximum well-being. Both Maslow and Rogers presuppose that counselors are able to help their patients selfactualize through slow-paced and gentle counseling (Benjamin \& Looby, 1998). In the individual-centered therapy developed by Rogers, a psychological counselor's work is holistic in nature. Focusing on the patient-counselor relationship with this perspective in mind, the patient is considered to be a free individual whose counseling sessions and environment are designed in such a way that he may be directed to discover every aspect of his self (Murdock, 2014).

In conclusion, not only Haji Baktash Walî, but alsoYûnus Emre and Jalâluddîn Rûmî are $13^{\text {th }}$ century men of hearts, all hailing from Anatolia, whose lofty spiritual values of doing good, virtuousness, love, peace, acceptance of others, seeking to help others, and self-sacrifice have come be accepted as universal values forming the base of what it means to be human today. When the historical period that these individuals lived is taken into consideration, it is observed that Anatolia was in a chaotic state, not only plagued by wars, pillaging, invasions, and massacres, but also experiencing a social crisis in which fear and hopelessness were omnipresent. During such social strife, these individuals emphasized the above-listed core values in an attempt to heal society of its spiritual wounds, encouraging individuals in their community to internalize the universalism found in their spiritual tradition. Haji Baktash Walî, as expressed in the universalism in his teaching of Four Doors - Forty Stations, delineates a natural psychological method that facilitates one's spiritual development so that he consciously accepts and internalizes his God-created nature, purpose of existence, and human values. Fast forwarding to the $20^{\text {th }}$ century, not only has humanist psychology identified a deep degree of social strife and an absence of values in society (anomy, alienation, emptiness, hopelessness, and a lack of ideals to belief in or sacrifice his life for), so too has it emphasized how powerless modern 
psychology is in its ability to provide for society's needs. Stressing universalism and holism, humanist psychology, basing its conclusion on data collected from peak experiences, approaches this problem of absence of values in society from a transcendental perspective that adopts universalism, unity, and infinity. In this vein, Haji Baktash Walî offers a unique perspective to solve the problem pertaining to society's "absence of values" with his idea that man is a complete whole, his emphasis on universal human values, and his transcendental perspective.

\section{References}

Aktürk, H., \& Tuğrul, T. (2014). Alevi-Bektaşi kaynaklarında insan yetiştirme modeli [Human raising model in Alevi and Bektashi sources]. Türk Kültürü ve Hacı Bektaş Velî Araştırma Dergisi, 72, 211-225.

Arasteh, R. A., \& Sheikh, A. E. (2003). Sufizm: Evrensel benliğe giden yol [Sufism: The road of universal self]. In K. Sayar (Ed.), Sufi psikolojisi [Sufi psychology] (pp. 51-97). İstanbul, Turkey: İnsan Yayınları.

Aytaş, G. (2010). Hacı Bektaş Velî ve Thomas More'da hümanizm [Humanism in Hacı Bektash Veli and Thomas More]. Türk Kültürü ve Hacı Bektaş Veli Araştırma Dergisi, 55, 139-148.

Benjamin, P., \& Looby, J. (1998). Defining the nature of spirituality in the context of Maslow's and Rogers's theories. Counseling and Values, 42(2), 92-100.

Birge, K. J. (1991). Bektaşilik tarihi [The history of Bektashism] (R. Çamuroğlu, Trans.) İstanbul, Turkey: Ant Yayınları.

Coşan, E. M. (2013). Makalat-ı Hacı Bektaş-ı Veli [Makalat of Hacı Bektash Veli]. İstanbul, Turkey: Server İletişim.

Çakmak, Y. (2015). Velayetname-i Hacı Bektaş-1 Veli bize neyi anlatır? [What does Velayetname of Haci, Bektash Veli tell us?]. In Y. Çakmak \& İ. Gürtaş (Eds.), Kızılbaşlık, Alevilik, Bektaşilik: Tarih, kimlik, inanç, ritüel [Qizilbash, Alevisim, Bektashism: History, identity, faith and rituels] (pp. 71-109). Ankara, Turkey: İletişim Yayınları.

Çetinkaya, B. A. (2009, August). Hacı Bektaş-ı Veli'de insan felsefesi [Human philosophy of Hacı Bektash Veli]. Paper presented at Doğumunun 800. yılında Hacı Bektaş-1 Veli Sempozyumu, Nevşehir, Turkey.

Durakoğlu, A. (2015). Hacı Bektaş Veli ve Soren Kierkegaard'ın ideal insan tipi [The perfect human for Hacı Bektash Veli and Soren Kierkegaard]. Türk Kültürü ve Hacı Bektaş Velî Araştırma Dergisi, 73, 49-66.

Eğri, O. (2001). Bektaşilik'te tasavvufi eğitim [Sufi training in bektashisim]. İstanbul, Turkey: Horasan Yayınları.

Elkins, D. N. (2007). A humanistic approach to spiritually oriented psychotherapy. In L. Sperry \& E. P. Shafranske (Eds.), Spiritually oriented psychotherapy (pp. 131-152). Washington, DC: APA.

Eröz, M. (1990). Türkiye'de Alevilik ve Bektaşilik [Alevism and Bektashism in Turkey]. Ankara, Turkey: Kültür Bakanlığı Yayınları.

Göçün, Ö. (1999). Hacı Bektaş-ı Veli ve "insan imajı" [Hacı Bektash Veli and "human image"]. In I. Türk Kültürü ve Hacı Bektaş-ı Veli Sempozyumu Bildirileri (pp. 143-153). Ankara, Turkey: Gazi Üniversitesi. 
Gölpınarlı, A. (1995). Vilayet-Name, "Manakab-ı Hünkar Hacı Bektaş-ı Veli”. İstanbul, Turkey: İnkilap Kitapevi.

Gübiz, A. (1966). İrade hürriyeti [Free will]. Ankara Üniversitesi Hukuk Fakültesi Dergisi, 22(1), 636-673.

Güray, C. (2010). Semâ'dan Semah'a bir sonsuz devir [An endless cycle from Sema to Semah]. Türk Kültürü ve Hacı Bektaş Veli Araştırma Dergisi, 56, 119-152.

Karacoşkun, M. D. (2007). İbnü'l-Arabî'de insan psikolojisine yaklaşımlar ve kişilik çözümlemeleri [Personality analysis and aproaches to human psychology of Ibn Arabi]. Dinbilimleri Akademik Araştırma Dergisi, 7(3), 71-108.

Kehl-Bodrogi, K. (2012). Kızılbaşlar/Aleviler [Qizilbashs] (O. Değirmenci \& B. E. Aybudak, Trans.). İstanbul, Turkey: Ayrıntı Yayınları.

Korkmaz, E. (1999). Hacı Bektaş-1 Veli öğretisi: Dört kapı kırk makam [Hacı Bektash Veli’s doctrine: Four gates-forty stations]. In I. Türk Kültürü ve Hacı Bektaş-l Veli Sempozyumu Bildirileri (pp. 143-153). Ankara, Turkey: Gazi Üniversitesi.

Kurşunoğlu, M. S. (2014). Doğu düşüncesinde hermetik ruhsal simya tecrübesi ve Hac1 Bektaş-1 Velî’nin Makâlâtı [Hermetic spiritual alchemy experience in eastern thought and Makalat of Hac1 Bektash Veli]. EKEV Akademi Dergisi, 58(58), 605-628.

Kuzgun, Y. (1972). Kendini gerçekleştirme [Self-actualization]. Araştırma Ankara Üniversitesi Dil ve Tarih-Coğrafya Fakültesi Felsefe Bölümü Dergisi, 10(1), 162-178.

Küçüközyiğit, U. (2014). Hacı Bektaş-1 Veli’nin mesajı ve Bektaşiliğin güçlenmesinde etkili olan dinamikler [Haci Bektas Veli's message and the dynamics that effective in strengthening the Bektashism]. Türk Kültürü ve Hacı Bektaş Velî Araştırma Dergisi, 72, 227-239.

Maslow, A. (1996). Dinler, değerler, doruk deneyimler [Religions, values and peak-experiences] (K. Sönmez, Trans.). İstanbul, Turkey: Kuraldış1.

Melikoff, I. (2010a). Hacı Bektaş, efsaneden gerçeğe [Hacı Bektash, from a myth to reality] (T. Alptekin, Trans.). İstanbul, Turkey: Cumhuriyet Kitapları.

Melikoff, I. (2010b). Bektaşilik/Kızılbaşlık tarihsel bölünme ve sonuçları [Historical divisions and the results in Bektashism/Qizilbash]. In T. Olsson, E. Ozdalga \& C. Raudvere (Eds.), Alevi kimliği [Alevi identity] (B. K. Torun \& H. Torun, Trans.). İstanbul, Turkey: Tarih Vakfi Yurt Yayınları.

Murdock, L. N. (2014). Psikolojik danışma ve psikoterapi kuramları [Theories of counseling and psychotherapy] (F. Akkoyun, Trans.). Ankara, Turkey: Nobel Yayıncılık.

Ocak, Y. A. (2008). Türk sufiliğine bakışlar [Aspects on Turkish sufi]. İstanbul, Turkey: İletişim Yayınları.

Odyakmaz, N. (1988). Bektaşilik, Meslevilik ve Masonluk [Bektashisim, Mevleviyeh and Masonry]. Ankara, Turkey: İnkilap Kitabevi.

Öz, B. (1997). Bektaşilik nedir? [What is Bektashisim]. İstanbul, Turkey: Der Yayınları.

Özelsel, M. M. (2002). Halvette 40 gün: Psikolog dervişin halvet günlügü ve bilimsel çözümlemesi [Forty days in solitude: The solitude journal of psychologist dervish and the scientific analysis] (P. B. Ateş, Trans.). İstanbul, Turkey: Kaknüs Yayınları.

Powers, R. L. (2003). Robert L. Powers's original contribution to "Spirituality in the Adlerian Forum.” Journal of Individual Psychology, 59(1), 84-85. 
Sayar, K. (2003). Geçmişin bilgeliği bugününün psikoterapileriyle buluşabilir mi? [Can the wisdom of past meet with today's psyhotherapies]. In K. Sayar (Ed.), Sufi psikolojisi [Sufi psychology] (pp. 17-50). İstanbul, Turkey: İnsan Yayınları.

Schultz, P. D., \& Schultz, E. S. (2006). Modern psikoloji tarihi [History of modern psychology] (Y. Aslay, Trans.). İstanbul, Turkey: Kaknüs Yayınları.

Sever, M. (2009). Kaygusuz Abdâl'ın Menâkıbnâmesine ve şiirlerine göre insanın manevî eğitimi [Spiritual training of human by Kaygusuz Abdal's hagiography and poetry]. Dergi Karadeniz, $17,58-67$.

Shankland, D. (2010). Antropoloji ve etnisite: Yeni Alevi hareketinde etnografyanın yeri [Anthropology and ethnicity: The place of etnography in new alevi movement]. In T. Olsson, E. Ozdalga \& C. Raudvere (Eds.), Alevi kimliği [Alevi identity] (B. K. Torun \& H. Torun, Trans., pp. 21-34). İstanbul: Tarih Vakfi Yurt Yayınları.

Şimşek, H. İ. (2015). Tasavvufî tecrübelerin mahremiyeti meselesi [Privacy issues of mystical experiences]. Hitit Üniversitesi Illahiyat Fakültesi Dergisi, 14(28), 115-128.

Yıldırım, R. (2015). Bektaşi kime derler? "Bektaşi” kavramının kapsamı ve sınırları üzerine tarihsel bir analiz denemesi [Who is bektashi? A historical analysis essay on the scope and limits of the concept of the Bektashi]. In Y. Çakmak \& I Gürtaş (Eds.), Kızılbaşlık, Alevilik, Bektaşilik: Tarih, kimlik, inanç, ritüel [Qizilbash, Alevisim, Bektashism: History, identity, faith and rituels] (pp. 55-71). Ankara, Turkey: İletişim Yayınları. 